\title{
SPEECH PERCEPTION ABILITIES IN INDIVIDUALS WITH AUDITORY NEUROPATHY SPECTRUM DISORDER WITH PRESERVED TEMPORAL SYNCHRONY
}

\author{
H.S. Chandan ${ }^{1}$, P. Prashanth Prabhu ${ }^{2}$ \\ ${ }^{1}$ Department of POCD, All India Institute of Speech and Hearing, Manasagangothri, Mysore, India \\ ${ }^{2}$ Department of Audiology, All India Institute of Speech and Hearing, Manasagangothri, Mysore, India
}

Corresponding author: Prashanth Prabhu P., Department of Audiology, All India Institute of Speech and Hearing, Manasagangothri, Naimisham Campus, Mysore, Karnataka, India 570006, Tel: +91-8904353390, e-mail: prashanth.audio@gmail.com

\begin{abstract}
Background: The auditory brainstem response (ABR) is usually abnormal in individuals with auditory neuropathy spectrum disorder (ANSD). However, in some such individuals the ABR is preserved at low repetition rates. This study attempts to understand the speech perception abilities of ANSD individuals who have preserved temporal synchronicity.

Material and methods: There were 149 individuals with ANSD in the study. They were classified into two groups based on preserved or absent ABR. Speech identification scores (SISs) in these individuals in quiet and in the presence of noise were compared.
\end{abstract}

Results: At low repetition rates some $12.5 \%$ of subjects had preserved ABR with low amplitude wave V. Of these, $81 \%$ had an SIS of more than $50 \%$ in quiet. However, in patients with absent ABR, only $27 \%$ of individuals had an SIS of more than $50 \%$. For subjects who had preserved ABR the mean SIS was $73.1 \%$ in quiet and $36.5 \%$ in noise compared to $35.9 \%$ in quiet and $20.2 \%$ in noise for individuals who had absent ABR.

Conclusions: One in eight of the patients with ANSD had preserved ABR. Speech understanding was also better in quiet and in the presence of noise in individuals with preserved ABR. We conclude that speech reception abilities depend upon neural synchronicity at the level of the auditory nerve.

Key words: auditory neuropathy spectrum disorder • speech identification scores • preserved ABR • absent ABR • temporal synchrony

\section{CAPACIDAD DE PERCEPCIÓN DEL HABLA EN PERSONAS CON NEUROPATÍA AUDITIVA MANTENIENDO PROCESAMIENTO TEMPORAL DE ESTÍMULOS}

\section{Resumen}

Introducción: En personas con neuropatia auditiva (ANSD), los potenciales auditivos evocados del tronco cerebral (ABR) son, por lo general, incorrectos. Sin embargo, en algunas personas podemos registrar las respuestas ABR con baja frecuencia de repetición del estímulo. El presente estudio tiene por objetivo dar a entender en qué consiste la capacidad de recepción del habla en personas que sufren ANSD con mantenimiento de la sincronización temporal.

Materiales y método: En el estudio han participado 149 personas con ANSD. Según los resultados de ABR, estas personas han sido divididas en dos grupos: primer grupo de personas con las que ha sido imposible registrar la respuesta ABR y otro grupo, donde sí ha sido posible registrarla. Se ha realizado la comparación de resultados de entendimiento de habla (SIS) en estas personas en el silencio y en el ruido.

Resultados: En un 12.5\% de los participantes del estudio, en las frecuencias bajas de repetición de estímulos, se han registrado las respuestas con la amplitud de la onda V reducida. De este grupo, en la prueba del entendimiento del habla en el silencio, un $81 \%$ ha conseguido el resultado de identificación de palabras superior a 50\%. En los pacientes en los que no ha sido posible registrar la respuesta $\mathrm{ABR}$, tan sólo un $27 \%$ ha conseguido el resultado superior a $50 \%$ en pruebas del entendimeinto del habla. En los pacientes con respuestas ABR preservadas, el resultado medio de las preubas SIS fue de $73 \%$ en silencio y de $36.5 \%$ en ruido, mientras en los pacientes con respuestas no registradas el resultado medio fue respectivamente de $35.9 \%$ en silencio y de $20.2 \%$ en ruido. 
Conclusiones: En uno de cada ocho pacientes con neuropatía auditiva se consigue registrar las respuestas ABR. El entendimiento del habla en el silencio es mejor en personas en las que se pueden registrar las respuestas ABR. Nuestra conclusión es que la capacidad de recepción del habla depende de la sincronización de las descargas en neuronas del nervio auditivo.

Palabras clave: neuropatía auditiva $\bullet$ resultados del entendimiento del habla • mantenimiento de la respuesta ABR • sincronización temporal

\section{ВОЗМОЖНОСТЬ ВОСПРИЯТИЯ РЕЧИ ЛЮДЬМИ СО СЛУХОВОЙ НЕЙРОПАТИЕЙ С СОХРАНЕННОЙ ВРЕМЕННОЙ ОБРАБОТКОЙ ИМПУЛЬСОВ}

\section{Изложение}

Введение: У людей со слуховой нейропатией (ANSD) стволомозговые слуховые вызванные потенциалы (ABR) обычно неправильные. Однако у некоторых людей можно зарегистрировать ответы ABR при низких частотах повторения импульса. Цель настоящей работы - это осмысление того, в чем заключается умение восприятия речи у людей, страдающих ANSD с сохраненной временной синхронизацией.

Материалы и методы: В исследовании участвовало 149 пациентов с ANSD. В зависимости от результатов ABR пациенты были разделены на 2 группы - те, у которых не удалось зарегистрировать ответ ABR и те, у которых удалось зарегистрировать ответ ABR. У этих пациентов были сравнены результаты понимания речи (SIS) в тишине и в шуме.

Результаты: Приблизительно у $12.5 \%$ исследованных людей были зарегистрированы при низких частотах повторений импульсов ответы со сниженной амплитудой волны V. Среди них у $81 \%$ человек в тесте понимания речи в тишине результаты идентификации слов составили более 50\%. Среди пациентов, у которых не удалось зарегистрировать ответа ABR, только $27 \%$ человек получило результат более 50 ?\% в тестах на понимание речи. У пациентов с сохраненными ответами ABR средний результат тестов SIS - 73\% в тишине и 36.5\% в шуме, тогда как у пациентов с незарегистрированными ответами средний результат составил $35.9 \%$ в тишине и $20.2 \%$ в шуме.

Итоги: У одной восьмой части пациентов со слуховой нейропатией можно зарегистрировать ответы ABR. Понимание речи в тишине - лучше у людей, у которых можно зарегистрировать ответы ABR. Мы утверждаем, что умение восприятия речи зависит от синхронизации разрядов в нейронах слухового нерва.

Ключевые слова: слуховая нейропатия • результаты понимания речи • сохранение ответа ABR • временная синхронизация

\section{ZDOLNOŚĆ PERCEPCJI MOWY U OSÓB Z NEUROPATIĄ SŁUCHOWA Z ZACHOWANYM CZASOWYM PRZETWARZANIEM BODŹCÓW}

\section{Streszczenie}

Wstęp: U osób z neuropatią słuchową (ANSD) słuchowe potencjały wywołane pnia mózgu (ABR) są zazwyczaj nieprawidłowe. Jednak u niektórych osób możemy zarejestrować odpowiedzi ABR przy niskich częstościach powtarzania bodźca. Niniejsza praca ma na celu zrozumienie, na czym polega umiejętność odbioru mowy u osób cierpiących na ANSD z zachowaną czasową synchronizacją.

Materiał i metoda: W badaniu wzięło udział 149 pacjentów z ANSD. W zależności od wyników ABR pacjenci zostali podzieleni na 2 grupy - tych u których nie udało się zarejestrować odpowiedzi ABR, i tych u, których udało się zarejestrować odpowiedzi ABR. Porównano wyniki rozumienia mowy (SIS) u tych pacjentów w ciszy i w szumie.

Wyniki: U około 12,5\% badanych zarejestrowano przy niskich częstościach powtarzania bodźców odpowiedzi o obniżonej amplitudzie fali V. Z tego $81 \%$ osób uzyskało w teście rozumienia mowy w ciszy wynik identyfikacji słów wynoszący ponad 50\%. Wśród pacjentów, u których nie udało się zarejestrować odpowiedzi ABR tylko 27 osób uzyskało wynik ponad 50\% w testach na rozumienie mowy. U pacjentów z zachowanymi odpowiedziami ABR średni wynik testów SIS wynosił 73\% w ciszy i 36,5\% w szumie, podczas gdy u pacjentów z niezarejestrowanymi odpowiedziami średni wynik wynosił 35,9\% w ciszy i 20,2\% w szumie.

Podsumowanie: U jednego na ośmiu pacjentów z neuropatią słuchową udaje się zarejestrować odpowiedzi ABR. Rozumienie mowy w ciszy jest lepsze u osób, u których można zarejestrować odpowiedzi ABR. Stwierdzamy, że umiejętność odbioru mowy zależy od synchronizacji wyładowań w neuronach nerwu słuchowego.

Słowa kluczowe: neuropatia słuchowa $\bullet$ wyniki rozumienia mowy • zachowanie odpowiedzi ABR • synchronizacja czasowa 


\section{Background}

Auditory neuropathy spectrum disorder (ANSD) is a condition in which a patient's outer hair cells are normal (giving a normal otoacoustic emission response) but there is an absent/abnormal auditory brainstem (ABR) response [1]. In some instances, when otoacoustic emissions (OAEs) are abnormal, ANSD is identified on the basis of the presence of cochlear microphonics (CM) and abnormal or absent ABRs [2-4]. The overall incidence of ANSD varies from $11 \%$ to $0.54 \%$ of the hearing-impaired population $[5,6]$. Picton [7] reported that 90-95\% of all cases of ANSD are bilateral. ANSD may be present in some $10-15 \%$ of all children with hearing loss and ANSD may be present in higher percentages (15-20\%) among children with severeto-profound hearing loss [8]. However, Shivashankar et al. [9] reported that in all the 24 patients they studied the onset of the problem occurred during the first and second decade of life, except for one where the onset was at age 44 years. This clinical data was gathered over a period of 10 years from a tertiary referral institution in South India. Similarly, in another retrospective study carried out in South India, Kumar and Jayaram [6] reported that 59\% of their 61 patients with ANSD had an onset between 14 to 24 years of age. Prabhu et al. [10] reported the onset of ANSD at puberty in the majority of their patients.

ANSD is diagnosed based on multiple behavioural and electrophysiologic tests such as ABR, OAE, CM, acoustic reflexes, word recognition scores, and speech perception in noise (SPIN) [7]. The pure-tone audiogram of a person with ANSD may range from normal hearing sensitivity to profound hearing loss $[1,11]$. Speech recognition ability can be good in quiet and deteriorate in the presence of noise [12]. This variability in clinical features implies different degrees of the same pathology or disruption of various parts of the auditory pathways. This disruption may be at the level of the inner hair cells, the synapse, or the auditory nerve itself $[3,13,14]$. The timing of neural signals in the auditory pathway is disrupted in individuals with ANSD $[15,16]$. The affected ears struggle to track rapidly occurring changes in the amplitude or frequency of auditory signals. Several investigators have demonstrated that disruption of temporal processing ability could explain the variability in speech perception across listeners with ANSD [11,17].

There are reports of variation in ABR findings in individuals with ANSD. The ABR is reported to be absent or abnormal at maximum stimulus levels regardless of the behavioral hearing level $[1,17]$. This result may be due to a reduction in the total number of neural elements available to contribute to the response, or to overall disruption in the temporal integrity of the neural signal. Starr et al. [18] observed preserved Wave $\mathrm{V}$ without a preceding Wave I from 13 (21\%) of 60 patients with ANSD. They also reported that Wave $\mathrm{V}$ was preserved in a minority of patients with ANSD, suggesting that the disorder may be due to temporal synchrony problems. It also provides evidence that neural synchrony can be partially preserved in some subjects with this disorder.

The above findings suggest that there might be a relationship between speech perception ability and preserved ABR since there is less disruption of temporal integrity in individuals with ANSD. However, there are no studies of individuals with ANSD which assess their speech perception abilities and their ABR findings. The present study attempts to do so.

\section{Material and Methods}

\section{Participants}

The number of patients with ANSD was determined using a register-based study design. Individuals diagnosed as having ANSD by the Department of Audiology, All India Institute of Speech and Hearing, between September 2000 and December 2012 were reviewed retrospectively. There were 149 individuals (297 ears) diagnosed as having ANSD during that period who had adequate speech and language; in these subjects a speech identification score (SIS) test was administered. Of the 149 patients with ANSD, 95 were female and 54 were male. All were diagnosed as having bilateral ANSD except one patient who had unilateral ANSD. The mean age of the patients with ANSD was 16.7 (s.d. 6.7) for males and 14.8 (s.d. 7.9) for females. The age range was 13-22 years for males and 10-21 for females.

ANSD was diagnosed based on the criteria recommended by Starr et al. [19]. They were: preserved cochlear amplification (reflected by the presence of transient evoked otoacoustic emissions and/or cochlear microphonics); altered auditory nerve responses (as indicated by absent or severely abnormal ABRs); and normal otologic and tympanometric findings with absent acoustic reflexes. A detailed neurological examination was carried out on all participants to rule out any space-occupying lesion, with a detailed clinical neurologic examination that also included radiologic investigations such as CT/MRI. All were diagnosed as having primary or Type I ANSD [3] without any associated neurological problems and/or syndromes. The detailed audiological evaluation included pure-tone audiometry, speech audiometry, immittance evaluation, otoacoustic emissions and/or cochlear microphonics, and ABR.

\section{Testing procedure and instruments}

Case records indicated that all subjects had been tested under standard conditions. All had been tested with calibrated audiometers in sound-treated rooms. Pure-tone testing had been done using a modified Hughson and Westlake procedure [20]. Immittance evaluation (tympanometry and acoustic reflex threshold testing) for a $226-\mathrm{Hz}$ probe tone had been carried out with a calibrated middle ear analyzer (GSI 33 or Tympstar v 2.0). The transient evoked otoacoustic emissions had been measured using a calibrated OAE analyzer (ILO 292 or ILO v6 DP Echoport).

\section{Auditory brainstem response recording}

Auditory brainstem response testing had been done using a Biologic Navigator or IHS Smart EP (version 3140) evoked potential system. An identical protocol was used to test all patients. ABR recording was carried out using a click stimulus with insert phones (ER3A) positioned in the subjects' ear canals and disposable $\mathrm{Ag} / \mathrm{AgCl}$ surface electrodes placed on their vertex $(\mathrm{Cz})$ (non-inverting) and over 
Table 1. ABR findings in 297 ears with ANSD

\begin{tabular}{ccc}
\hline Response & Number (ears) & Percentage (\%) \\
\hline Absent ABR & $260 / 297$ & 87.5 \\
\hline Preserved ABR & $37 / 297$ & 12.5 \\
\hline
\end{tabular}

the mastoid of their test ear (M1 or M2) (inverting) and non-test ear (M2 or M1 as ground). Electrode impedances were maintained at less than $2 \mathrm{k}\{\mathrm{U}$. ABR waveforms were first recorded by stimulating each ear with click stimuli at $90 \mathrm{dBnHL}$ at $11.1 \mathrm{clicks} / \mathrm{s}$ and at $90.1 \mathrm{clicks} / \mathrm{s}$ using both rarefaction (two traces per ear) and condensation polarities (two traces per ear). All ABR signals were amplified 100,000 times, recorded for $10.24 \mathrm{~ms}$ (click) post-stimulus, averaged over 2048 samples, and filtered from 100-3000 $\mathrm{Hz}$, while the non-test ear was masked with white noise at the test ear stimulus level minus $40 \mathrm{~dB}$. Along with ABR recordings, a long-ringing $\mathrm{CM}$ was clearly recorded in a few of the participants. The records confirmed that ABR testing had been done twice to ensure reproducibility of waveforms. A group of 30 normal hearing adults had been tested to establish nHL values.

\section{Speech Identification Scores (SIS)}

Speech Identification Scores (SIS) were obtained through monitored live voice presentation using headphones. Word lists for adults developed by Yathiraj and Vijayalakshmi [21] were used to obtain the SIS at $40 \mathrm{~dB}$ SL (re: SRT). A speech perception in noise test was also administered at $0 \mathrm{~dB}$ SNR with headphones using the word list developed by these same authors.

\section{Neurological evaluation}

All patients underwent a neurological examination by a qualified neurologist. This included clinical neurological examination and/or CT scan and/or MRI.

\section{Ethical considerations}

In the present study, all the testing procedures involved non-invasive techniques and adhered to conditions set by the ethical approval committee of the All India Institute of Speech and Hearing, Mysore. All test procedures were explained to the patients and their family members before testing and informed consent to participate in the study was received from all patients or their family members.

\section{Results}

\section{Auditory brainstem response (ABR)}

Recorded ABRs were classified as absent ABR or preserved ABR based on the following criteria. ABR was noted as absent when there was absence of all components of the $\mathrm{ABR}$ at $90 \mathrm{~dB} \mathrm{nHL}$ at the $11.1 / \mathrm{sec}$ repetition rate. ABR was classified as preserved when components of ABR (low amplitude wave V, with or without wave III) were present at $90 \mathrm{~dB} \mathrm{nHL}$ at the $11.1 / \mathrm{sec}$ rate but absent at the $90.1 / \mathrm{sec}$ repetition rate. ABR findings for the individuals included in the database are summarised in Table 1; even when present, ABRs had a very low amplitude wave V. Table 1 shows that ABR was absent in 260 ears (87.5\%), whereas it was preserved in only $37(12.5 \%)$ subjects. The mean amplitude of Wave $\mathrm{V}$ when present ( $37 \mathrm{AN}$ ears) was 0.10 $\{\mathrm{mV}$, which was significantly less $(p<0.01)$ than the mean amplitude of Wave V in normals $(0.51\{\mathrm{mV})$. The latency of Wave $\mathrm{V}$ was delayed in 25 ears (6 ms to $8 \mathrm{~ms}$ ). Figure 1 shows sample waveforms of subjects with ABR present (Figure 1A) and ABR absent (Figure 1B). The figure shows that long-ringing cochlear microphonics were present in both subjects, confirming the diagnosis of auditory neuropathy spectrum disorder.

\section{Speech Identification Score (SIS)}

Out of the patients who had preserved ABR, $81 \%$ of the ears tested had speech identification scores more than $50 \%$
A

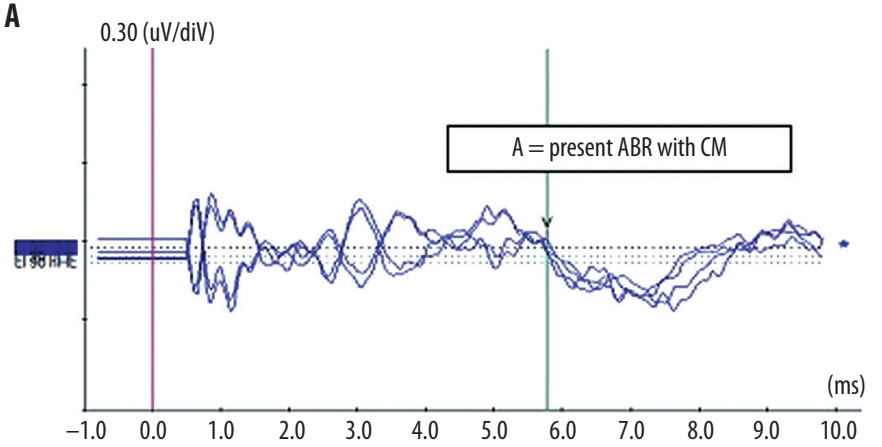

Figure 1. $A B R$ waveform of two patients; (A) with $A B R$ present and (B) with absent $A B R$ with long ringing cochlear microphonics

B

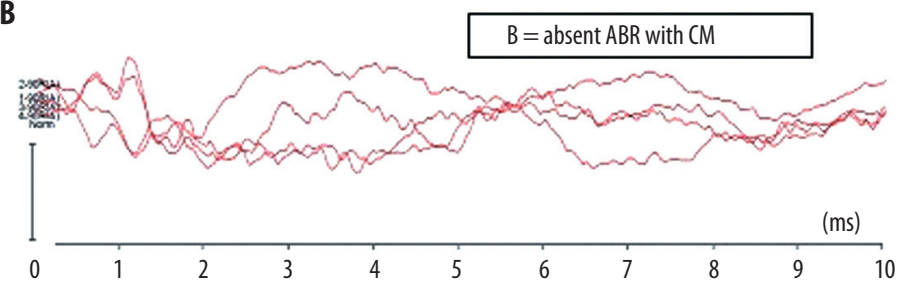


Table 2. Speech identification scores in individuals with absent and preserved ABR

\begin{tabular}{ccccc}
\hline & \multicolumn{3}{c}{ SIS $\mathbf{5 0 \%}$} & \multicolumn{2}{c}{ SIS $<\mathbf{5 0 \%}$} \\
\cline { 2 - 5 } & Ears & Percent (\%) & Ears & Percent (\%) \\
\hline Absent ABR & $72 / 260$ & 27.7 & $188 / 260$ & 72.3 \\
\hline Preserved ABR & $30 / 37$ & 81.1 & $07 / 37$ & 18.9 \\
\hline
\end{tabular}

Table 3. Average speech identification scores (SIS) in quiet (for subjects where SIS $>0 \%$ ) and average SIS in presence of noise (for 34 subjects in whom SPIN was administered)

\begin{tabular}{ccc}
\hline $\begin{array}{c}\text { Speech } \\
\text { Identification Score }\end{array}$ & Mean & Standard deviation \\
\hline $\begin{array}{c}\text { Preserved ABR } \\
\text { (quiet) }\end{array}$ & $73.1 \%$ & $25.0 \%$ \\
\hline $\begin{array}{c}\text { Preserved ABR } \\
\text { (noise) }{ }^{* *}\end{array}$ & $36.5 \%$ & $25.3 \%$ \\
\hline $\begin{array}{c}\text { Absent ABR (quiet) } \\
* * *\end{array}$ & $35.9 \%$ & $27.1 \%$ \\
\hline Absent ABR (noise) & $20.2 \%$ & $15.5 \%$ \\
\hline$* * * *$ &
\end{tabular}

* 19 subjects (37 ears) had SIS >0\%; ** For 7 subjects speech in noise test was administered at $0 \mathrm{~dB}$ SNR using speech noise with preserved ABR findings; *** 94 subjects (177 ears) had SIS $>0 \%$; ${ }^{* * * *}$ For 27 subjects speech in noise test was administered at $0 \mathrm{~dB}$ SNR using speech noise with absent ABR findings.

and the remaining $19 \%$ of the ears had scores less than $50 \%$. In patients with absent $\mathrm{ABR}$, only $28 \%$ of the ears tested had SIS greater than $50 \%$ and the remaining $72 \%$ of the ears had scores less than 50\%, as shown in Table 2 .

The average SIS in quiet and in the presence of noise $(0$ dB SNR) for patients with preserved and absent ABRs are shown in Table 3. Speech perception in the presence of noise is not a routine test and is administered only on a few subjects. SPIN data was available only for 34 subjects from the overall patient data considered. The SPIN scores obtained in these individuals were considered for analysis. The mean SIS was $73.1 \%$ in quiet and $36.5 \%$ in noise for subjects who had preserved ABR and it was only $35.9 \%$ in quiet and $20.2 \%$ in noise in individuals who had absent ABR. A Mann-Whitney $U$-test was performed to check for significant difference in SIS for quiet and noise conditions across both groups with ANSD. In quiet condition, the result shows that there was highly significant difference $(U=2019, Z=3.63, p<0.01)$ in SIS between individuals with preserved and absent $\mathrm{ABR}$. In the presence of noise there was also a significant difference $(U=234.5, Z=2.19, p<0.05)$ in SIS across both groups of the study.

\section{Discussion}

The present study attempted to examine the relation between variation in $\mathrm{ABR}$ findings and speech perception abilities in individuals with ANSD. The ABR obtained was classified as preserved or absent ABR. The preserved $\mathrm{ABR}$ was noted in $12.5 \%$ of ears, which is lower than that reported by Staar et al. [18]. A reason could be the difference in the number of patients considered for the study. Staar et al. [18] considered only 66 ears, whereas in the present study 297 ears were evaluated. The result obtained in the present study is in consensus with reports of Starr et al. [18] who suggest that neural synchrony can be preserved in some individuals with ANSD. Starr et al. [18] reported that preserved (though low amplitude) wave $\mathrm{V}$ occurred in a minority of individuals with ANSD, suggesting that the disorder of temporal synchrony can be graded as ANSD. The above findings provide further evidence that neural synchrony can be partially preserved in some subjects with ANSD and the dys-synchronous firing is graded as ANSD.

The ABR is dependent on the precise synchronous responses of a group of auditory nerve fibers to a transient acoustic stimulus. In individuals with ANSD, there is disruption of the normal synchronous activity in the auditory nerve $[3,17]$. In the present study, it was found that ABR was absent in $87.6 \%$ of individuals with ANSD. This result is consistent with previous reports which suggest that abnormal ABR findings are due to temporal asynchrony in individuals with ANSD $[1,3,22]$. The exact reason for temporal disruption in patients with ANSD is unclear. It is assumed to be because of loss of inner hair cells or loss of spike synchrony resulting from damaged nerve fibers [3,23-25]. This results in the average evoked potential of the ABR being absent in individuals with ANSD.

The results of the study showed that SIS was relatively better when ABR was preserved and the scores were reduced in patients with absent ABR. The results also show that scores in the presence of noise were better in those ANSD individuals who had preserved ABR. The overall poor speech perception results observed in individuals with ANSD in the present study is similar to those reported in other studies $[15,16,26]$. The reason for poor SIS in individuals with ANSD is probably disrupted neural synchrony $[3,15,16]$. Disordered neural synchrony results in abnormal temporal and spectral processing $[16,15,26]$ which leads to an inability to use envelope cues in speech or to perceive rapid changes in spectral shapes of speech stimuli $[11,27]$. Thus, in patients with preserved ABR, there could be less disruption at the level of the auditory nerve; in this case synchronicity is partially preserved and there is better speech understanding. The result of the study also shows that preserved synchronicity at the level of auditory nerve can also lead to better understanding of speech in presence of noise in individuals with ANSD. Thus, the results of the study may be useful in identifying the varieties or sub-groups of patients with ANSD. 


\section{Conclusions}

The present study tried to understand the relation between variation in $\mathrm{ABR}$ and speech understanding abilities in individuals with ANSD. The study shows that one in eight of the patients with ANSD had preserved ABR. The result also showed that speech understanding was better in quiet and in the presence of noise in individuals with preserved ABR. Thus, the study showed that speech reception abilities depend upon neural synchronicity at the level of the auditory nerve. The study adds to the evidence that a group of individuals with ANSD exist who have lesser temporal synchrony but who still have relatively preserved speech understanding.

\section{Conflict of Interest Statement}

The authors report no conflicts of interest. The authors alone are responsible for the content and writing of the paper.

\section{References:}

1. Berlin CI, Hood LJ, Morlet T, Wilensky D, Li L, Mattingly KR et al. Multi-site diagnosis and management of 260 patients with auditory neuropathy/dys-synchrony (Auditory neuropathy spectrum disorder). Int J Audiol, 2010; 49: 30-43.2. Berlin C, Hood L, Morlet T, Rose K, Brashears S. Auditory neuropathy/dys-synchrony: diagnosis and management. Ment Retard Dev Disabil Res Rev, 2003; 9: 225-31.

3. Starr A, Picton TW, Sininger Y, Hood LJ, Berlin CI. Auditory neuropathy. Brain, 1996; 119: 741-53.

4. Deltenre P, Mansbach AL, Bozet C, Christiaens F, Barthelemy $\mathrm{P}$ et al. Auditory neuropathy with preserved cochlear microphonics and secondary loss of otoacoustic emissions. Audiology, 1999; 38: 187-95.

5. Tang TP, Mcpherson, B, Yuen KC, Wong, LL, Lee JS. Auditory neuropathy/auditory dys-synchrony in school children with hearing loss: Frequency of occurrence. I J Pediatr Otolaryngol, 2004; 168: 175-83.

6. Kumar AU, Jayaram M. Prevalence and audiological characteristics in individuals with auditory neuropathy/dys-synchrony. Int J Audiol, 2006; 45: 360-66.

7. Picton TW. Auditory neuropathy - when time is broke. $\mathrm{Hu}-$ man Auditory-Evoked Potentials. Plural Publishing Inc., 2011

8. Hood LJ, Morlet T. Current issues in auditory neuropathy spectrum disorder. In Tremblay KE, Burkard RF. (eds.). Translational Perspectives in Auditory Neuroscience. Plural Publishing, 2012

9. Shivashankar N, Satishchandra P, Shashikala HR, Gore M. Primary auditory neuropathy - an enigma. Acta Neurol Scand, 2003; 108: 130-35.

10. Prabhu P, Avilala VKY, Manjula P. Predisposing factors in individuals with late onset auditory dys-synchrony. Asia Pac J Speech Lang Hear, 2012; 15(1): 41-50.

11. Rance, G, Barker, EJ. Speech and language outcomes in children with auditory neuropathy/dys-synchrony managed with either cochlear implants or hearing aids. Int J Audiol, 2009; 48(6): 313-20.

12. Rance G, Barker EJ, Sarant JZ, Ching TY. Receptive language and speech production in children with auditory neuropathy/ dyssynchrony type hearing loss. Ear Hear, 2007; 28: 694-702.

13. Rance, G, Beer DE, Cone-Wesson B, Shepherd HK, Dowell RLC, King AM et al. Clinical findings for a group of infants and young children with auditory neuropathy. Ear Hear, 1999; 20: $238-52$
14. Amatuzzi MG, Northrop C, Liberman MC, Thornton A, Halpin C, Herrmann B et al. Selective inner hair cell loss in premature infants and cochlea pathological patterns from neonatal intensive care unit autopsies. Arch Otolaryngol Head Neck Surg, 2001; 127: 629-36.

15. Zeng FG, Oba S, Grade S, Sininger Y, Starr A. Temporal and speech processing deficits in AN. Neuroreport, 1999; 10: 3429-35.

16. Rance G, McKay C, Grayden D: Perceptual characterization of children with auditory neuropathy. Ear Hear, 2004; 25: 34-46.

17. Sininger $Y, O b a S$. Patients with auditory neuropathy: who are they and what can they hear? In: Sininger Y, Starr A (eds.), Auditory neuropathy: A new perspective on hearing disorders. San Diego: Singular Publishing, 2001; pp. 15-35

18. Starr A, Sininger YS, Nguyen T et al. Cochlear receptor (microphonic and summating potentials, otoacoustic emissions) and auditory pathway (auditory brainstem potentials) activity in auditory neuropathy. Ear Hear, 2001; 22: 91-99.

19. Starr A, Sininger $Y$, Pratt $H$. The varieties of auditory neuropathy. J Basic Clin Physiol Pharmacol, 2000; 11: 215-30.

20. Carhart R, Jerger JF. Preferred method for clinical determination of pure-tone thresholds. J Speech Hear Disord, 1959; 24: $330-45$.

21. Yathiraj A, Vijayalakshmi CS. Auditory memory test. A test developed at the Department of Audiology, AIISH, Mysore, 2005.

22. Rance G. Auditory neuropathy/dys-synchrony and its perceptual consequences. Trends in Amplification, 2005; 9: 1-43.

23. Harrison RV. An animal model of auditory neuropathy. Ear Hear, 1998; 19: 355-61.

24. Moore BC. Dead regions in the cochlea: Conceptual foundations, diagnosis, and clinical applications. Ear Hear, 2004; 25 : 98-116.

25. Wang J, Powers NL, Hofstetter P, Trautwein P, Ding D, Salvi IL. Effects of selective inner hair cell loss on auditory nerve fiber threshold, tuning and spontaneous and driven discharge rate. Hear Res, 1997; 107(1-2): 67-82.

26. Zeng FG, Kong YY, Michalewski HJ, Starr A. Perceptual consequences of disrupted auditory nerve activity. J Neurophysiol, 2005; 93(6): 3050-63.

27. Narne VK, Vanaja CS. Perception of Envelope Enhanced Speech in Presence of Noise by individuals with Auditory Neuropathy. Ear Hear, 2009; 30: 136-42. 